\title{
Postbloom Thinning of 'Bartlett' Pear with Metamitron
}

\author{
Mokhles A. Elsysy \\ Department of Horticulture, Michigan State University, 1066 Bogue Street, \\ East Lansing, MI 48824; and Department of Pomology, College of \\ Agriculture, Assiut University, Assiut 71515, Egypt
}

\section{Andrew Hubbard}

Department of Horticulture, Oregon State University, Mid-Columbia Agricultural Research and Extension Center, 3005 Experiment Station Drive, Hood River, OR 97031

\section{Todd C. Einhorn}

Department of Horticulture, Michigan State University, 1066 Bogue Street, East Lansing, MI 48824; and Department of Horticulture, Oregon State University, Mid-Columbia Agricultural Research and Extension Center, 3005 Experiment Station Drive, Hood River, OR 97031

Additional index words. crop load management, fruit abscission, fruit set, photosynthesis, PS II inhibition

\begin{abstract}
Metamitron is a relatively new postbloom thinning compound for pome fruits that inhibits the photosystem II (PS II) pathway of photosynthesis. Reduced assimilation of carbohydrate by metamitron action may lead to a carbohydrate deficit that promotes fruit abscission. We have evaluated the thinning efficacy of metamitron rate and, to a limited extent, application timing for 'Bartlett' pear in five separate trials over 3 years (2015-17) in northern Oregon. Comparisons were made to a nontreated control and, depending on the trial, a commercial standard thinning compound [benzyladenine (6BA) or abscisic acid (ABA)]. Application timings ranged between 7- and 16-mm fruit diameter depending on the trial. Metamitron markedly inhibited photosynthesis (PN), typically for a duration of 2 to 3 weeks, although longer persistence was observed in two trials. Generally, PN was reduced linearly with increasing metamitron rate, but the effect varied by rate and year and may have been enhanced by high temperatures. Metamitron effectively thinned in four of five trials whereby pear fruit set was negatively and linearly related to rate. Rates of 200 to $300 \mathrm{ppm}$ were efficacious and produced target crop loads. In only one trial, increasing concentrations $(600 \mathrm{ppm})$ led to greater thinning. Metamitron significantly thinned 'Bartlett' pears when applied between 10 and $13 \mathrm{~mm}$. In contrast, early application timing $(\approx 7 \mathrm{~mm})$ had little effect on fruit abscission. Fruit size increased with decreasing crop load and thus was significantly improved by metamitron. Interaction between biological and environmental factors likely contributed to year-to-year variability in efficacy.
\end{abstract}

Bloom and postbloom thinning is essential to managing yield and fruit quality in modern pear production systems. Much of the 'Bartlett' pear acreage in the western United States comprises well-established trees planted at low to medium density. These relatively large canopies necessitate ladders for most horticultural management practices, including thinning. These orchards continue to be productive and profitable, but under the current and future labor situations, economically sustainable alternatives to hand thinning will need to be developed.

Received for publication 10 Oct. 2019. Accepted for publication 6 Nov. 2019.

Published online 3 January 2020.

T.C.E. is the corresponding author. E-mail: einhornt@ msu.edu.

This is an open access article distributed under the CC BY-NC-ND license (https://creativecommons. org/licenses/by-nc-nd/4.0/). (i.e., during bloom) facilitates consistent annual flower production (Lakso et al., 1996). Although 'Bartlett' pear fruit size and quality benefit from thinning, the cultivar does not exhibit strong biennial bearing characteristics. Thus, less importance is placed on bloom thinning pear than apple. However, most pear growers prefer to wait until after bloom to develop a postbloom thinning strategy. Thinning after bloom provides time to consider bloom strength and pollinator activity in addition to avoiding the risk of episodic frost events during or immediately after bloom. Thus, pear producers need chemical compounds with good postbloom efficacy given the relatively narrow timeframe that fruit remain sensitive to thinners and the cost-prohibitive task of hand thinning in the event that chemical thinning was insufficient.

Metamitron is a triazinone herbicide that was introduced to several countries relatively recently as a pomefruit (apple and pear) thinning compound. The mode of action is PSII inhibition via electron transport blockage, which reduces maximum potential quantum efficiency of PSII (Fv/Fm). Metamitron was shown to persist for 7 to $10 \mathrm{~d}$ in both apple and peach at concentrations of 100 to $500 \mathrm{ppm}$ (McArtney et al., 2012). These responses were associated with fruit abscission, but only apple fruit set was dose dependent (McArtney et al., 2012). Reports from European and U.S. metamitron trials indicate a wide range of thinning efficacy for apple (Basak, 2011; Brunner et al., 2014; Greene et al., 2013, 2014).

Relative to pear, there have been few published articles documenting the thinning efficacy of metamitron. Maas and van der Steeg (2011) reported positive thinning results for 'Conference' pear using rates of 175 to 300 $\mathrm{ppm}$. These trials were conducted in The Netherlands, and physiological and environmental data were not provided. Because climatic factors would be expected to influence efficacy (Greene, 2002), there is a need to evaluate thinners in the region of potential use. This may be particularly true when translating results from the former study to the Pacific northwestern United States, which has comparatively higher solar radiation levels than The Netherlands. 'Conference' pear also has a markedly different fruit bearing habit than 'Bartlett' (Sansavini and Musacchi, 1994).

Metamitron is not yet registered for use in the United States. Therefore, the objective of this study was to evaluate the efficacy of metamitron as a postbloom thinner for 'Bartlett' pears in one of the major U.S. pear production regions. We conducted multiple trials to generate sufficient thinning response data under a range of environmental conditions and diverse plant material (varying primarily in age but also canopy architecture) to determine the potential of metamitron as a pear thinner.

\section{Materials and Methods}

Five separate experiments were conducted to test the efficacy of metamitron on fruit 
abscission and yield parameters between 2015 and 2017 using 'Bartlett' pear orchards in four different pear production regions of Oregon, United States: Hood River, Wamic, The Dalles, and Parkdale. A surfactant was not added to metamitron, and applications were made to drip using a hydraulic, pressurized spray gun. Depending on the trial, a commercially available thinner was also evaluated.

Metamitron applications were planned when fruitlet diameter was between 7 and $16 \mathrm{~mm}$ (directly measured in each orchard by randomly sampling 100 fruitlets from five to 10 trees). The exact timing of application was dependent on weather conditions and thus varied somewhat because all applications were made under dry, calm conditions (i.e., wind speed $<5 \mathrm{~km} \cdot \mathrm{h}^{-1}$ ). In 2015 and 2017, metamitron was additionally evaluated at two phenology stages. For each experiment, the total number of trees was selected from the orchard for uniformity of canopy size and bloom. Treatments were then randomly assigned using a randomized complete block design (RCBD). Replication varied depending on the trial. All other production practices were performed according to industry standards, except for hand thinning, which was only performed in Expt. 2 after June drop, whereby fruit were removed from each tree to achieve the optimal crop load desired by the orchard manager. The total number of handthinned fruit from each tree was recorded.

\section{Expt. 1 (2015)}

A 35-year-old 'Bartlett'/OH $\times \mathrm{F} 51$ freestanding, multileader orchard $(3.7 \times 5.5 \mathrm{~m}$, 498 trees/ha) was selected at the Oregon State University Mid-Columbia Agricultural Research and Extension Center in Hood River, OR (lat. 45.7, long. -121.5). Treatments were arranged in a RCBD with four single-tree replicates. Blocks comprised single rows and were separated by guard rows. Within blocks, treatment trees were separated by a minimum of one guard tree to decrease the risk of spray drift. Rates were applied as follows, 1) $0 \mathrm{ppm}$ (control), 2) $150 \mathrm{ppm}$ metamitron, 3) 300 ppm metamitron, and 4) 600 ppm metamitron. Two application timings were evaluated on separate trees and in combination, 7.2- and 10.9-mm fruitlet diameter, applied 23 Apr. and 27 Apr., respectively.

\section{Expt. 2 (2016)}

A 12-year-old 'Bartlett'/OH $\times$ F $97(3 \times$ $6 \mathrm{~m} ; 556$ trees/ha) free-standing, central leader planting was selected in a commercial orchard in Parkdale, OR (lat. 45.3, long. -121.3). Treatments were arranged in a RCBD with six single-tree replicates. Blocks and individual treatment trees were separated by a minimum of one guard tree to decrease the risk of spray contamination. The following treatments were applied: 1) $0 \mathrm{ppm}$ (control), 2) $100 \mathrm{ppm}$ metamitron, 3) $200 \mathrm{ppm}$ metamitron, 4) 300 ppm metamitron, 5) 400 ppm metamitron, and 6) $100 \mathrm{ppm}$ 6-BA (MaxCel, Valent BioSciences LLC, Libertyville, IL). A surfactant was used with 6-BA
(Sil 100; Clariant Corp., Mount Holly, NC) at $0.1 \%(\mathrm{v} / \mathrm{v})$. All treatments were applied at 11.5-mm fruit diameter on 7 May 2016.

\section{Expt. 3 (2016)}

A 4-year-old 'Bartlett' $/ \mathrm{OH} \times \mathrm{F} 87$ commercial orchard $(1.2 \times 3.7 \mathrm{~m} ; 2243$ trees/ ha), trained as a single axis to a four-wire trellis by positioning limbs horizontally on trellis wires, was selected in Wamic, OR (lat. 45.2, long. -121.3). Treatments were arranged in a RCBD with five three-tree replicates. Blocks comprised single rows and were separated by several guard rows. Within blocks, treatment trees were separated by a minimum of one guard tree to decrease the risk of spray drift. The following treatments were applied: 1) 0 ppm (control), 2) $250 \mathrm{ppm}$ metamitron, and 3) 500 ppm metamitron. Treatments were applied at $12.7-\mathrm{mm}$ fruit diameter on 2 May 2016. For yield and fruit quality data, the three trees were harvested individually and treated as subsamples and data were pooled to generate replicate means.

\section{Expt. 4 (2016)}

Two research orchards were selected at the Oregon State University Mid-Columbia Agricultural Research and Extension Center in Hood River, OR (lat. 45.7, long. -121.5): An 11-year-old planting of 'Bartlett' $/ \mathrm{OH} \times \mathrm{F}$ $97(3 \times 4.9 \mathrm{~m} ; 672$ trees/ha) and a 20 -year-old planting of 'Bartlett'/OH $\times \mathrm{F} 87(2.4 \times 5.5 \mathrm{~m}$; 747 trees/ha), referred to as Site A and B, respectively. Both orchards were trained to a central leader and were free-standing. Treatments were arranged in a RCBD with four single-tree replicates in each orchard. Blocks comprised single rows and were separated by guard rows. Within blocks, treatment trees were separated by a minimum of one guard tree to decrease the risk of spray contamination. The following treatments were applied: 1) $0 \mathrm{ppm}$ (control), 2) $125 \mathrm{ppm}$ metamitron, 3) $250 \mathrm{ppm}$ metamitron, 4) $500 \mathrm{ppm}$ metamitron, and 5) $125 \mathrm{ppm}$ 6-BA (MaxCel). Treatments were applied at $12.4-\mathrm{mm}$ fruit diameter on 21 Apr. 2016.

\section{Expt. 5 (2017)}

An 8-year-old 'Bartlett'/OH×F $97(2.4 \times$ $5.3 \mathrm{~m} ; 769$ trees/ha) free-standing, central leader planting was selected in a commercial orchard located in The Dalles, OR (lat. 45.6, long. -121.2). Treatments were arranged in RCBD with four single-tree replicates. Blocks and treatment trees were separated by a minimum of one guard tree to decrease the risk of spray contamination. The following treatments were applied: 1) 0 ppm (control), 2) $180 \mathrm{ppm}$ metamitron, 3) $270 \mathrm{ppm}$ metamitron, 4) $360 \mathrm{ppm}$ metamitron, 5) 95 ppm 6-BA (MaxCel), and 6) 250 ppm ABA (ProTone, Valent BioSciences LLC, Libertyville, IL). A surfactant (Sil 100; Clariant Corp., Mount Holly, NC) was used for 6$\mathrm{BA}$ and $\mathrm{ABA}$ at $0.1 \%(\mathrm{v} / \mathrm{v})$. Metamitron treatments were applied at two timings to different trees, 15 May and 19 May 2017 when fruitlet diameter was 8 and $13 \mathrm{~mm}$, respectively. ABA and 6-BA treatments were only applied on 19 May 2017.

Leaf gas exchange. Leaf gas exchange measurements were taken on four fully mature, sunlit leaves from current season growth per replicate with a portable infrared gas analyzer (IRGA) system (CIRAS-3, PP Systems, Amesbury, MA). The CIRAS-3 calculates photosynthesis rate (i.e., flux, $\mu \mathrm{mol} \cdot \mathrm{m}^{-2} \cdot \mathrm{s}^{-1}$ ) from direct measures (via two IRGAs) of the $\mathrm{CO}_{2}$ concentration entering and exiting the leaf cuvette, relative to the leaf area in the cuvette $\left(4.5 \mathrm{~cm}^{2}\right) . \mathrm{CO}_{2}$ concentration was controlled (390 ppm, $\pm 1 \mathrm{ppm}$ ) and delivered via a $\mathrm{CO}_{2}$ soda cartridge. All measurements were performed at this concentration. Measurements were taken on days when PAR exceeded $1200 \mu \mathrm{mol} \cdot \mathrm{m}^{-2} \cdot \mathrm{s}^{-1}$, which is greater than the photosynthetic light saturation of pear leaves (Einhorn et al., 2012).

Fruit set, yield, and quality attributes. A minimum of two and no more than four scaffold limbs per replicate were selected at bloom, and the total number of flower clusters per limb was counted. Scaffolds possessed a minimum of 50 clusters and typically had closer to 100 . A sufficient number of limbs were selected per replicate to provide $\approx 200$ total flower clusters for fruit set estimates. After June drop $(\approx 40 \mathrm{~d}$ after full bloom), the number of fruit on each scaffold limb was counted, and fruit set was expressed as the number of fruit per cluster. In the case of Expt. 3, the total number of clusters per tree was counted since trees were younger than those of other trials (i.e., fourth leaf).

Individual trees of an experiment were harvested in one event based on the average flesh firmness of the orchard block. Yield (kilograms) was estimated for each tree and the total number of fruit per tree was counted. Average fruit size was determined by dividing the total number of fruit into the yield. A randomly selected 20 -fruit sample per replication was collected at harvest, and in Expts. 3 through 6, an additional 20 fruit per replication were collected and stored in regular air $\left[-1{ }^{\circ} \mathrm{C}( \pm 0.5),>95 \%\right.$ relative humidity] for $90 \mathrm{~d}$ and then ripened for $5 \mathrm{~d}$ at $20{ }^{\circ} \mathrm{C}$ before fruit quality analyses. For all analysis dates, fruit firmness (FF) was measured on two sites per fruit (opposite one another) using an automated penetrometer (Fruit Texture Analyzer; Güss Manufacturing, Strand, South Africa) after removing an $\approx 5 \mathrm{~cm}^{2}$ area of skin. A pooled sample comprising one wedge taken from each of the 20 pears per replicate was juiced for $30 \mathrm{~s}$ in a juice extractor (Acme 6001, Acme Juicer Manufacturing Co., Sierra Madre, CA) to measure soluble solids concentration (SSC) and titratable acidity (TA). SSC was determined using a digital refractometer (Model PR-101; ATAGO Co., Ltd., Bellevue, WA). TA was quantified using an automated titration system (Model DL15; Mettler-Toledo, LLC, Columbus, $\mathrm{OH}$ ) by titrating a $10-\mathrm{mL}$ juice sample in $10 \mathrm{~mL}$ of DI water to an endpoint $\mathrm{pH}$ of 8.1 with $0.1 \mathrm{~N}$ $\mathrm{NaOH}$. 
Table 1. Expt. 1: Effect of 2015 metamitron whole canopy spray applications on fruit set, production, and fruit quality attributes of 35 -year-old 'Bartlett'/OH $\times \mathrm{F} 51$ pear trees at the Oregon State University, Mid-Columbia Agricultural Research and Extension Center in Hood River, OR. Data are means of four single-tree replicates. Linear regression effect and adjusted $R^{2}$ of control treatment and three concentrations $(150,300$, and $600 \mathrm{ppm})$ of metamitron applied at either $7.2-$ or 10.9-mm fruitlet diameter or both timings $(7.2+10.9 \mathrm{~mm})$.

\begin{tabular}{|c|c|c|c|c|c|c|c|c|c|}
\hline \multicolumn{2}{|c|}{ Treatment } & \multirow[b]{2}{*}{ Fruit set (no./cluster) } & \multicolumn{2}{|c|}{ Yield } & \multirow[b]{2}{*}{ Fruit wt (g) } & \multirow[b]{2}{*}{ Fruit vol $\left(\mathrm{cm}^{3}\right)$} & \multirow[b]{2}{*}{$\mathrm{SSC}(\%)$} & \multirow[b]{2}{*}{ TA $(\%)$} & \multirow[b]{2}{*}{$\mathrm{FF}(\mathrm{kg})$} \\
\hline Time & $\overline{\mathrm{ppm}}$ & & (no./tree) & $\overline{(\mathrm{kg} / \text { tree })}$ & & & & & \\
\hline Control 0 & & 0.51 & 1021.5 & 172.0 & 189.1 & 923.0 & 12.1 & 0.37 & 8.0 \\
\hline $7.2 \mathrm{~mm}$ & 150 & 0.46 & 919.8 & 160.5 & 192.3 & 1181.2 & 12.1 & 0.39 & 7.9 \\
\hline $7.2 \mathrm{~mm}$ & 300 & 0.43 & $752.8 *$ & 128.1 & 186.9 & 1133.2 & 12.4 & 0.37 & 7.8 \\
\hline $7.2 \mathrm{~mm}$ & 600 & 0.46 & $734.4 *$ & 138.8 & $210.3^{*}$ & 1214.8 & 11.5 & 0.42 & 7.9 \\
\hline \multicolumn{2}{|c|}{ Significant (linear) } & NS & $*$ & NS & $*$ & NS & NS & NS & NS \\
\hline \multicolumn{2}{|c|}{ Adjusted $R^{2}$} & & 0.28 & & 0.20 & & & & \\
\hline $10.9 \mathrm{~mm}$ & 150 & $0.36^{*}$ & $484.6^{* * *}$ & $102.4 * * *$ & $233.7 * * *$ & 1323.7 & 12.0 & $0.44 * * *$ & 8.2 \\
\hline $10.9 \mathrm{~mm}$ & 300 & $0.30 * *$ & $436.2 * * *$ & $98.4 * * *$ & $237.9 * * *$ & 1324.6 & 11.9 & $0.44 * * *$ & 8.3 \\
\hline $10.9 \mathrm{~mm}$ & 600 & $0.20 * * *$ & $330.0 * * *$ & $75.3 * * *$ & $246.9 * * *$ & 1383.0 & 12.3 & $0.46^{* * *}$ & $8.6^{*}$ \\
\hline \multicolumn{2}{|c|}{ Significant (linear) } & $* * *$ & $* * *$ & $* * *$ & $* * *$ & NS & NS & $* * *$ & $*$ \\
\hline \multicolumn{2}{|c|}{ Adjusted $R^{2}$} & 0.64 & 0.82 & 0.69 & 0.68 & & & 0.79 & 0.18 \\
\hline $7.2+10.9 \mathrm{~mm}$ & 150 & $0.34^{* *}$ & $490.4 * * *$ & $109.8 * * *$ & $240.8 * * *$ & 1349.5 & 11.9 & 0.41 & 8.1 \\
\hline $7.2+10.9 \mathrm{~mm}$ & 300 & $0.22 * * *$ & $393.4 * * *$ & $87.7 * * *$ & $250.6 * * *$ & 1380.1 & 11.8 & $0.46^{* *}$ & 8.3 \\
\hline $7.2+10.9 \mathrm{~mm}$ & 600 & $0.21 * * *$ & $342.5 * * *$ & $72.2 * * *$ & $236.5 * * *$ & 1323.0 & 12.1 & $0.45^{* *}$ & 8.4 \\
\hline \multicolumn{2}{|c|}{ Significant (linear) } & $* * *$ & $* * *$ & $* * *$ & $* * *$ & NS & NS & $* *$ & NS \\
\hline \multicolumn{2}{|l|}{ Adjusted $R^{2}$} & 0.73 & 0.87 & 0.79 & 0.20 & & & 0.41 & \\
\hline
\end{tabular}

NS, $* * *, * * *$ Nonsignificant or significant at $P<0.05,0.01$, or 0.001 , respectively.

$\mathrm{SSC}=$ soluble solids concentration; $\mathrm{TA}=$ titratable acidity; $\mathrm{FF}=$ fruit firmness.

Table 2. Expt. 2: Effect of 2016 metamitron and 6-BA whole canopy spray applications on fruit set, production, and quality attributes of 12-year-old 'Bartlett'/ $\mathrm{OH} \times \mathrm{F} 97$ pear trees at a commercial orchard in Parkdale, OR. Data are means of six single-tree replicates. Linear regression effect and adjusted $R^{2}$ of control treatment $(0 \mathrm{ppm})$ and four concentrations $(100,200,300$, and $400 \mathrm{ppm})$ of metamitron, and significant effect of each concentration of metamitron, as well as 100 ppm 6-BA.

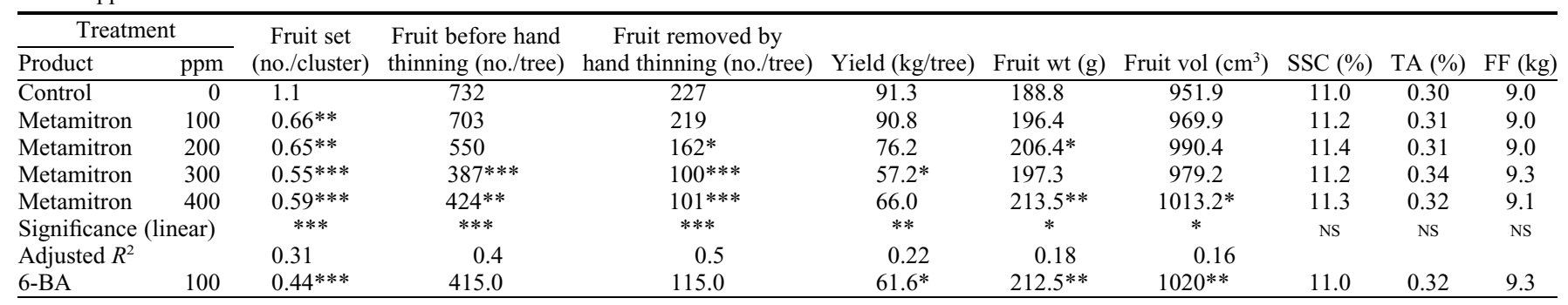

NS, *,**,***Nonsignificant or significant at $P<0.05,0.01$, or 0.001 , respectively.

$\mathrm{SSC}=$ soluble solids concentration; $\mathrm{TA}=$ titratable acidity; $\mathrm{FF}=$ fruit firmness

Solar radiation and temperature. Daily average, minimum, and maximum temperature and total incoming solar radiation $\left(\mathrm{W} \cdot \mathrm{m}^{-2}\right)$ were recorded at 15-min intervals and downloaded from the nearest weather stations to their respective orchard sites. For all experiments except Expt. 3, meteorological stations were located within $1 \mathrm{~km}$ of the trial sites. The nearest meteorological station to the commercial orchard in Expt. 3 was located in Pine Grove, OR (AgriMet, usbr.gov), which is $26.7 \mathrm{~km}$ from the trial but at a similar elevation.

Statistical analyses. All statistical analyses were performed with the $\mathrm{R}$ statistical package R (v. 3.4.3, R Foundation, Vienna, Austria). A mixed model ( $\operatorname{lm} 4$ package; Bates et al., 2015) was applied within experiments with blocking assigned as a random effect to compare individual treatment means to the control. In addition, for metamitron only, means for each response variable were fit to a linear function and significance at $P<$ 0.05 was reported along with $R^{2}$ values.

\section{Results}

Fruit set. Foliar application of metamitron significantly reduced fruit set in four of the five trials (Tables 1-5). Fruitlet abscission was differentially affected by the rate of metamitron and the developmental stage of fruit at the time of application (Tables 1-5). In 2015, a consistent, linear reduction in fruit set occurred with an increase in metamitron rate at $10.9 \mathrm{~mm}$ but not $7.2 \mathrm{~mm}$ (Table 1). In fact, thinning was not observed with the early treatment timing, and the combination of both timings did not produce higher abscission rates than the $10.9 \mathrm{~mm}$ timing alone. Results varied among the 2016 trials. In Parkdale, metamitron produced a significant linear thinning response between 100 and $400 \mathrm{ppm}$ (Table 2). In this trial, 6BA also resulted in significant fruit abscission compared with the control and had similar fruit set as the 300 and $400 \mathrm{ppm}$ metamitron treatments. For the second trial (Wamic, OR), a marked reduction in fruit set was observed for both 250 and $500 \mathrm{ppm}$, although $500 \mathrm{ppm}$ did not increase fruit abscission compared with 250 ppm (Table 3). In contrast to these trials, no thinning was observed at either site of the third trial (Hood River) irrespective of the compound (metamitron or 6-BA) or rate (Table 4). In 2017, metamitron significantly thinned at both timings, although a pronounced rate response was not evident (Table 5). At the earlier timing, thinning was improved at the mid and high rates (i.e., 270 and $360 \mathrm{ppm}$ ), and these treatments had markedly fewer fruit than either the ABA- or 6-BA-treated trees, both of which did not significantly differ from the control.

Yield and fruit quality. Yield responses generally agreed with the fruit set data (i.e., when treatments thinned, yield and fruit number were reduced; Tables 1-5). An increase in average fruit size and weight were associated with reduced yield. Depending on the year and trial, thinning treatments tended to produce fruit of optimal mass, between 200 and $250 \mathrm{~g}$ (Tables 1-5). Other fruit quality attributes were unaffected by treatments with the exception of TA, which was inconsistently higher for thinned treatments depending on the trial (Tables 1 and 5). Fruit firmness was increased in 2015 but only for one of the six thinning treatments. Treated fruit were generally firmer than control fruit, albeit nonsignificantly.

Solar radiation and temperature. Air temperature varied depending on the year (Fig. 1). Average temperature throughout the first week to $10 \mathrm{~d}$ after application was between 15 and $20{ }^{\circ} \mathrm{C}$ for three of the five trials. The exceptions were 2016, Hood River, where average temperatures were markedly lower, $\approx 10^{\circ} \mathrm{C}$ (Fig. 1G) and 2017, The Dalles, where they exceeded $20^{\circ} \mathrm{C}$ (Fig. 1I). The same trend was true of maximum air temperature. Hood 
Table 3. Expt. 3: Effect of 2016 metamitron whole canopy spray applications on fruit set, production, and quality attributes at harvest and after cold storage and a ripening treatment of 4-year-old 'Bartlett'/OH $\times \mathrm{F} 87$ pear trees in a commercial orchard in Wamic, OR. Data are means of five three-tree replicates. Linear regression effect and adjusted $R^{2}$ of the control treatment and two concentrations ( 250 and $500 \mathrm{ppm}$ ) of metamitron and significant effect of each concentration compared with control treatment. Application timing was 12.7-mm fruitlet diameter.

\begin{tabular}{|c|c|c|c|c|c|c|c|c|c|c|c|c|}
\hline \multicolumn{2}{|c|}{ Treatment } & \multirow{2}{*}{$\begin{array}{c}\text { Fruit set } \\
\text { (no./cluster) }\end{array}$} & \multicolumn{2}{|c|}{ Yield } & \multirow[b]{2}{*}{ Fruit wt (g) } & \multirow[b]{2}{*}{ Fruit vol $\left(\mathrm{cm}^{3}\right)$} & \multirow[b]{2}{*}{ SSC (\%) } & \multirow[b]{2}{*}{ TA $(\%)$} & \multirow[b]{2}{*}{$\mathrm{FF}(\mathrm{kg})$} & \multicolumn{3}{|c|}{ 3-mo $\mathrm{PH}^{\mathrm{z}}$} \\
\hline Product & ppm & & (no./tree) & $(\mathrm{kg} /$ tree $)$ & & & & & & SSC (\%) & $\mathrm{TA}(\%)$ & $\overline{F F}(\mathrm{~kg})$ \\
\hline Control & 0 & 0.24 & 111.7 & 22.7 & 204.1 & 378.3 & 12.5 & 0.4 & 8.8 & 13.3 & 0.34 & 1.2 \\
\hline Metamitron & 250 & $0.056 * * *$ & $26.7 * * *$ & $6.7 * * *$ & $248.1 * * *$ & 383.0 & 12.4 & 0.5 & 9.5 & 13.9 & 0.38 & 1.2 \\
\hline Metamitron & 500 & $0.071 * * *$ & $33.3 * * *$ & $7.9 * * *$ & $236.5 * * *$ & 378.4 & 11.9 & 0.4 & 9.3 & 14.0 & 0.37 & 1.2 \\
\hline $\begin{array}{l}\text { Significant }(1 \\
\text { Adjusted } R^{2}\end{array}$ & ar) & $\begin{array}{l}\text { *** } \\
0.58\end{array}$ & $\begin{array}{l}* * * \\
0.61\end{array}$ & $\begin{array}{l}* * * \\
0.59\end{array}$ & $\begin{array}{c}* * \\
0.37\end{array}$ & NS & NS & NS & NS & NS & NS & NS \\
\hline
\end{tabular}

z 3 -mo $\mathrm{PH}=3$ months postharvest regular air cold storage plus a 7-d ripening period at $20^{\circ} \mathrm{C}$.

NS, *,**,***Nonsignificant or significant at $P<0.05,0.01$, or 0.001 , respectively.

$\mathrm{SSC}=$ soluble solids concentration; $\mathrm{TA}=$ titratable acidity; $\mathrm{FF}=$ fruit firmness.

Table 4. Expt. 4: Effect of 2016 whole-canopy applications of metamitron and 6-BA on fruit set, production, and quality at harvest and after cold storage and a ripening treatment of 'Bartlett' pear trees in two research orchards located at the Oregon State University, Mid-Columbia Agricultural Research and Extension Center in Hood River, OR. Orchard A was a 12-year-old planting of 'Bartlett' on OH×F 97; orchard B was a 20-year-old planting of 'Bartlett' on OH $\times \mathrm{F} 87$. Application timing was $12.3-\mathrm{mm}$ fruitlet diameter. For each orchard, data are means of four single-tree replicates. Linear regression effect and adjusted $R^{2}$ of control treatment and three metamitron concentrations $(125,250$, and $500 \mathrm{ppm})$ and the significant effect of each concentration and $125 \mathrm{ppm} 6-\mathrm{BA}$ compared with the control treatment.

\begin{tabular}{|c|c|c|c|c|c|c|c|c|c|c|c|c|}
\hline \multicolumn{2}{|l|}{ Treatment } & \multirow{2}{*}{$\begin{array}{c}\text { Fruit set } \\
\text { (no./cluster) }\end{array}$} & \multicolumn{2}{|c|}{ Yield } & \multirow[b]{2}{*}{ Fruit wt $(\mathrm{g})$} & \multirow[b]{2}{*}{ Fruit vol $\left(\mathrm{cm}^{3}\right)$} & \multirow[b]{2}{*}{ SSC $(\%)$} & \multirow[b]{2}{*}{ TA (\%) } & \multirow[b]{2}{*}{$\mathrm{FF}(\mathrm{kg})$} & \multicolumn{3}{|c|}{ 3-mo $\mathrm{PH}^{\mathrm{z}}$} \\
\hline Product & $\overline{\mathrm{ppm}}$ & & (no./tree) & $\overline{(\mathrm{kg} / \text { tree })}$ & & & & & & $\overline{\mathrm{SSC}(\%)}$ & TA (\%) & FF (kg) \\
\hline Control & 0 & 0.45 & 263.8 & 61.0 & 213.4 & 393.4 & 10.8 & 0.29 & 8.1 & 11.6 & 0.21 & 1.9 \\
\hline Metamitron & 250 & 0.46 & 220.5 & 50.3 & $241.4 *$ & 401.1 & 11.4 & 0.30 & 8.1 & 12.0 & 0.24 & 1.3 \\
\hline Metamitron & 500 & 0.36 & 205.5 & 51.8 & $253.9 * *$ & 428.7 & 11.6 & 0.31 & 8.3 & 11.8 & 0.25 & 1.4 \\
\hline Significant (linear) & & NS & NS & NS & * & Ns & NS & NS & NS & NS & NS & NS \\
\hline Adjusted $R^{2}$ & & & & & 0.27 & & & & & & & \\
\hline $\begin{array}{l}\text { Control } \\
\text { Metamitron }\end{array}$ & $\begin{array}{r}0 \\
125\end{array}$ & 1.0 & $\begin{array}{l}270.8 \\
308.8\end{array}$ & $\begin{array}{l}56.9 \\
66.0\end{array}$ & $\begin{array}{l}204.4 \\
207.9\end{array}$ & $\begin{array}{l}385.8 \\
385.5\end{array}$ & $\begin{array}{l}11.9 \\
11.8\end{array}$ & $\begin{array}{l}0.36 \\
0.35\end{array}$ & 8.0 & $\begin{array}{l}12.3 \\
12.1\end{array}$ & $\begin{array}{l}0.27 \\
0.26\end{array}$ & $\begin{array}{l}1.0 \\
0.9\end{array}$ \\
\hline Metamitron & 250 & 0.99 & 254.3 & 55.9 & 213.9 & 382.8 & 11.6 & 0.36 & 8.0 & 12.5 & 0.26 & 0.9 \\
\hline Metamitron & 500 & 0.81 & 271.5 & 56.7 & 203.4 & 371.8 & 11.5 & 0.36 & 8.1 & 12.0 & 0.27 & 0.9 \\
\hline Significant (linear) & & NS & NS & NS & NS & NS & NS & NS & NS & NS & NS & NS \\
\hline $6-\mathrm{BA}$ & 100 & 1.1 & 290.3 & 63.3 & 212.2 & 378.6 & 11.5 & 0.35 & 8.0 & 12.3 & 0.27 & 1.2 \\
\hline
\end{tabular}

${ }^{\mathrm{z}} 3$-mo $\mathrm{PH}=3$ months postharvest regular air cold storage plus a 7 -d ripening period at $20{ }^{\circ} \mathrm{C}$.

NS, *,**,***Nonsignificant or significant at $P<0.05,0.01$, or 0.001 , respectively.

$\mathrm{SSC}=$ soluble solids concentration; $\mathrm{TA}=$ titratable acidity; $\mathrm{FF}=$ fruit firmness.

Table 5. Expt. 5: Effect of 2017 whole-canopy applications of metamitron, 6-BA (95 ppm) and ABA ( $250 \mathrm{ppm})$ on fruit set, production, and quality at harvest and after cold storage and a ripening treatment of 'Bartlett' pear trees in The Dalles, OR. Application timing was 9 and 14 mm. Data are means of four replicates. Linear regression effect and adjusted $R^{2}$ of control treatment and three concentrations (180, 270, and $360 \mathrm{ppm}$ ) of metamitron and the significant effect of each concentration and $95 \mathrm{ppm} 6-\mathrm{BA}$ and $250 \mathrm{ppm}$ ABA compared with the control treatment.

\begin{tabular}{|c|c|c|c|c|c|c|c|c|c|c|c|c|}
\hline \multicolumn{3}{|c|}{ Treatment } & \multirow{2}{*}{$\begin{array}{c}\text { Fruit set } \\
\text { (no./cluster) }\end{array}$} & \multicolumn{2}{|c|}{ Yield } & \multirow[b]{2}{*}{ Fruit wt $(\mathrm{g})$} & \multirow[b]{2}{*}{$\mathrm{SSC}(\%)$} & \multirow[b]{2}{*}{ TA $(\%)$} & \multirow[b]{2}{*}{ FF $(\mathrm{kg})$} & \multicolumn{3}{|c|}{ 3-mo $\mathrm{PH}^{\mathrm{z}}$} \\
\hline Product & Time & ppm & & (no./tree) & $\overline{(\mathrm{kg} / \text { tree })}$ & & & & & $\overline{\mathrm{SSC}(\%)}$ & TA (\%) & $\overline{F F(\mathrm{~kg})}$ \\
\hline Metamitron & $9 \mathrm{~mm}$ & 180 & $0.17 * * *$ & $70.9 * * *$ & $15.3 * *$ & $216.4 *$ & 13.2 & $0.67 *$ & 9.2 & 14.4 & 0.63 & 0.96 \\
\hline \multicolumn{3}{|c|}{ Significant (linear) } & $* * *$ & $* * *$ & $*$ & $*$ & NS & $*$ & NS & NS & $* *$ & NS \\
\hline \multicolumn{3}{|c|}{ Adjusted $R^{2}$} & 0.56 & 0.61 & 0.34 & 0.80 & & 0.26 & & & 0.52 & \\
\hline Metamitron & $14 \mathrm{~mm}$ & 180 & $0.10^{* * *}$ & $43.2 * * *$ & $9.6^{* * *}$ & 208.6 & 13.4 & $0.71 *$ & 9.5 & 15.1 & $0.71 * * *$ & 1 \\
\hline \multicolumn{3}{|c|}{ Significant (linear) } & $* * *$ & $* * *$ & $* * *$ & $* *$ & NS & $*$ & NS & NS & $* * *$ & NS \\
\hline \multicolumn{3}{|c|}{ Adjusted $R^{2}$} & 0.76 & 0.82 & 0.78 & 0.41 & & 0.24 & & & 0.67 & \\
\hline 6-BA & A & 95 & 0.42 & 97.7 & 19.4 & 193.6 & 13.8 & 0.57 & 9.1 & 14.9 & 0.57 & 0.88 \\
\hline ABA & A & 250 & 0.18 & $70.4 *$ & 15.3 & $204.7 *$ & 13.4 & 0.61 & 9.2 & 14.7 & 0.57 & 1 \\
\hline
\end{tabular}

${ }^{\mathrm{z}} 3$-mo $\mathrm{PH}=3$ months postharvest regular air cold storage plus a 7-d ripening period at $20^{\circ} \mathrm{C}$.

NS, $* * *, * * *$ Nonsignificant or significant at $P<0.05,0.01$, or 0.001 , respectively.

$\mathrm{SSC}=$ soluble solids concentration; $\mathrm{TA}=$ titratable acidity; $\mathrm{FF}=$ fruit firmness.

River (2016) was the only site where significant thinning did not result from the treatments (Table 4), and low temperatures immediately followed applications (Fig. 1G). The highest maximum air temperatures of $\approx 30{ }^{\circ} \mathrm{C}$ were observed at the 2016 (Wamic site) and 2017 trials. Diurnal solar radiation tended to fluctuate $\approx 800 \mathrm{~W} \cdot \mathrm{m}^{-2}$ (Fig. 1). Depending on the year, there were a few cloudy days characterized by low solar radiation at varying periods after application. Light levels were lower for 2016 Parkdale (Fig. 1D).
Photosynthesis. In all years, PN was reduced by metamitron (Fig. 2). Rate responses were detected but were often inconsistent and in several cases saturation occurred near 300 ppm (Fig. 2), as similarly observed for fruit set. Depending on the year, PN inhibition 


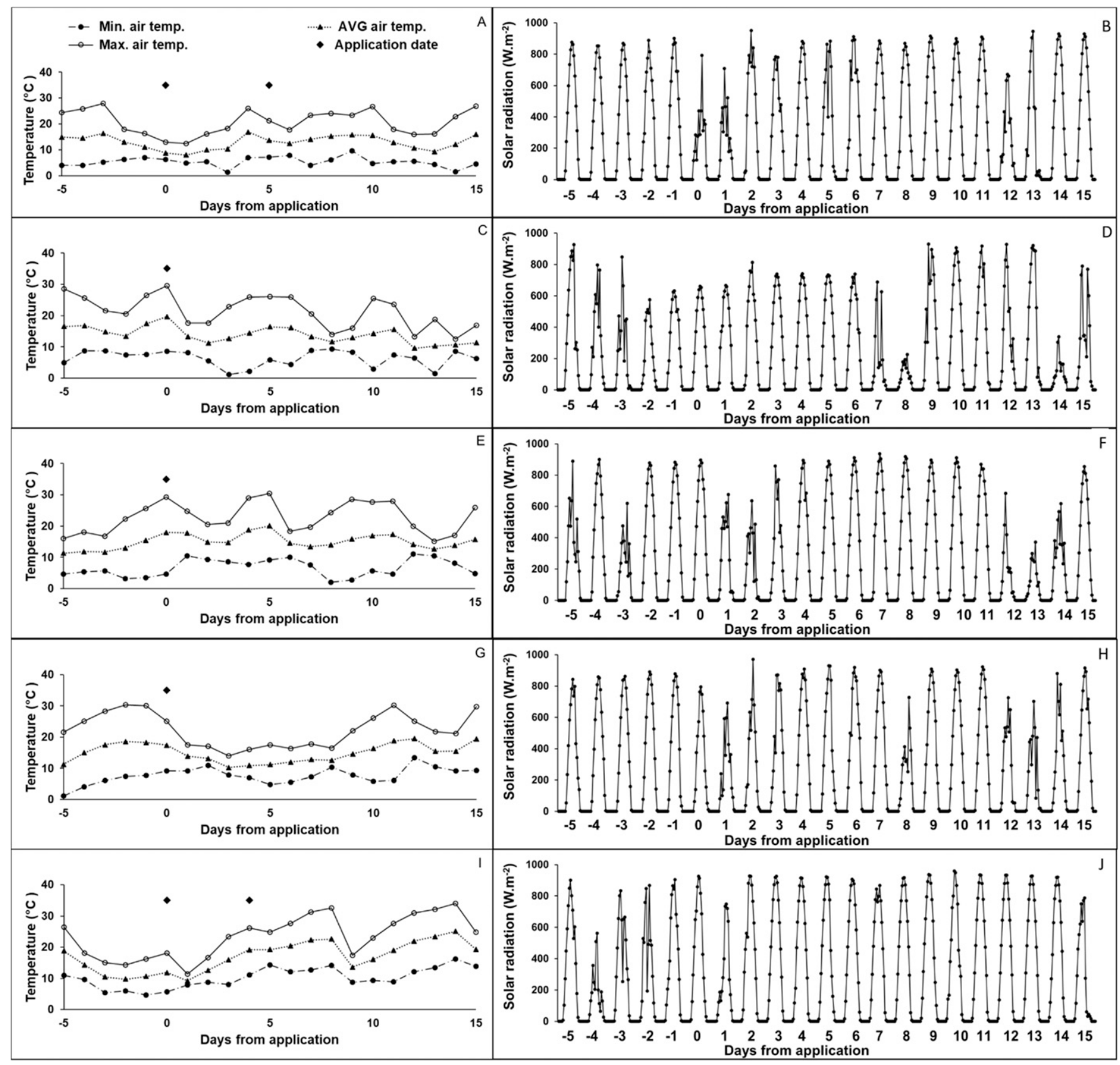

Fig. 1. Daily minimum, maximum and average temperature and diurnal traces of solar radiation $\left(\mathrm{W} \cdot \mathrm{m}^{-2}\right)$ at the five trial sites: Expt. $1(\mathbf{A}, \mathbf{B})$, Expt. $2(\mathbf{C}, \mathbf{D})$, Expt. $3(\mathbf{E}, \mathbf{F})$, Expt. $4(\mathbf{G}, \mathbf{H})$, and Expt. $5(\mathbf{I}, \mathbf{J})$. Meteorological stations were located within $1 \mathrm{~km}$ of trials for Expts. 1, 2, 4, and 5 and $26.7 \mathrm{~km}$ from Expt. 3.

from metamitron persisted for 3 weeks, with the longest lasting effect in 2017 , which may have been associated with the high maximum air temperatures recorded at this site (Fig. 1I). The compound 6-BA had no detectable effect on photosynthesis in the years it was measured (Fig. 2B and C).

\section{Discussion}

Our interest in evaluating metamitron was primarily due to its recent commercialization in several countries as a pome fruit thinner and the dearth of experimental data available for pear (Maas and van der Steeg, 2011). Compounds that inhibit PSII function, including metamitron, have been shown to successfully induce fruit abscission (Byers et al., 1985, 1986, 1990a, 1990b; Del Valle et al., 1985; Schröder, 2001). The thinning activity of metamitron on apple was associated with reduced $\mathrm{Fv} / \mathrm{Fm}$ values (McArtney et al., 2012). Indirect photosynthetic inhibition by ABA was also associated with fruitlet abscission of apple (McArtney et al., 2014) and pear (Arrington et al., 2017; Einhorn and Arrington, 2018); however, the consistent thinning of pear by ABA (Arrington et al., 2017; Cline et al., 2018; Greene, 2012) was not similarly demonstrated for apple (McArtney et al., 2014; Greene, 2012).

The reduced fruit set of 'Bartlett' pear by metamitron was associated with PN inhibition. Given the relatively strong fruit demand for carbohydrate and the inverse relationship between fruit growth rate and abscission (Greene and Lakso, 2013; Greene et al., 2013; Ward and Marini, 1999; Zucconi, 1981), foliar application of chemicals with the potential to suppress $\mathrm{PN}$ would be expected to reduce fruit set. PN was reduced between $50 \%$ and $90 \%$ within the first days from application. Persistence of metamitron, as expressed by PN inhibition, varied. The effect typically diminished with time but was still evident for more than 3 weeks after application. The photosynthetic response to metamitron was inconsistently affected by dose, but higher rates $(>300 \mathrm{ppm})$ often had no significant effect on PN compared with 200 ppm (Fig. 2). The degree to which metamitron reduced $\mathrm{PN}$ agreed with the fruit set and/or yield response. 

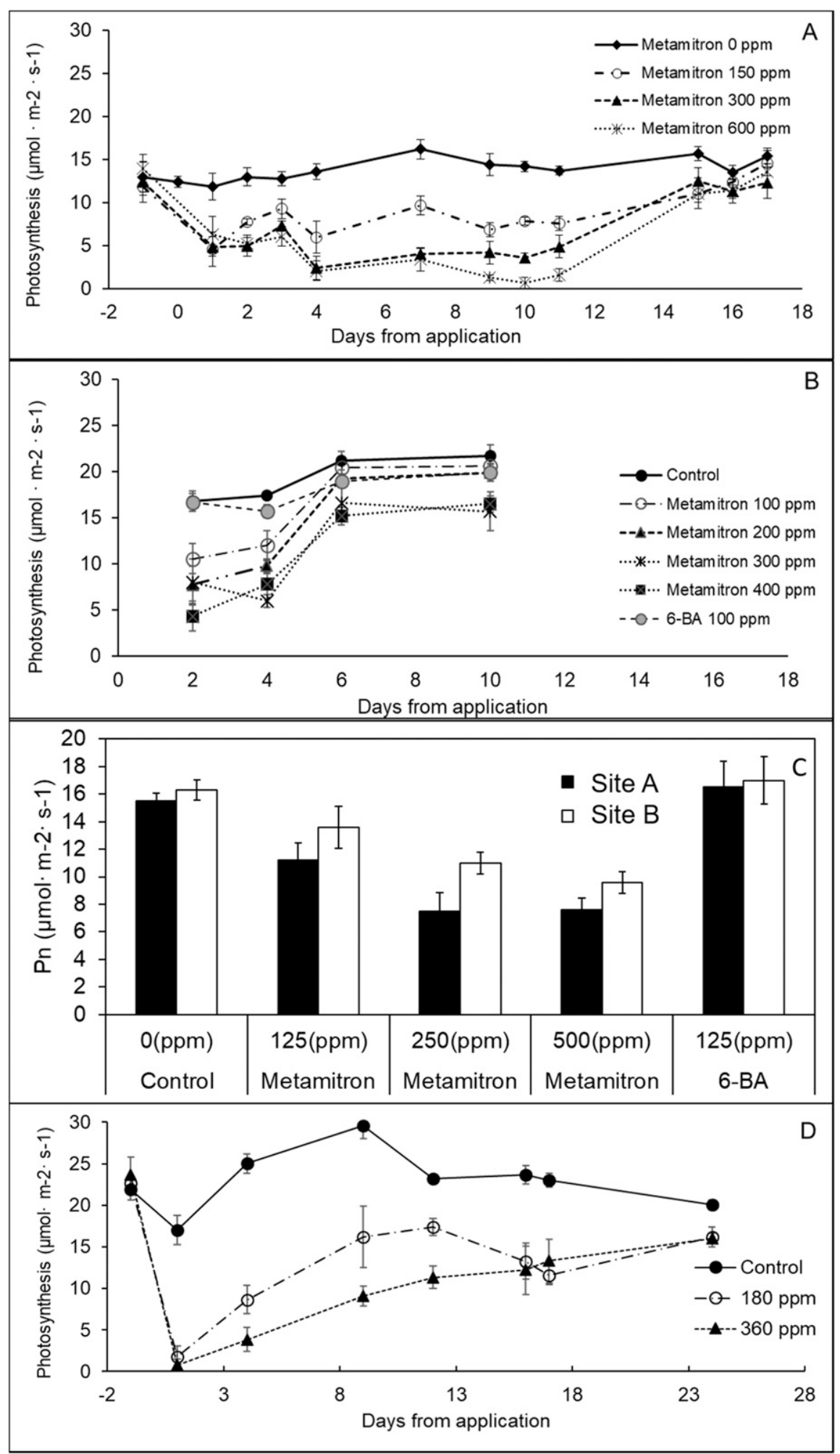

Fig. 2. The effect of Metamitron rate on photosynthesis (PN) of 'Bartlett' pear leaves in Expt. 1 (A), Expt. 2 (B), Expt. 4 (C), and Expt. 5 (D). For Expt. 4, PN data were collected 6 and $7 \mathrm{~d}$ after application for sites A and B, respectively. Measurements were taken at solar noon $( \pm 1 \mathrm{~h})$. Data are means of four replications $(n=4)$. Vertical bars are \pm 1 SE.

The lack of thinning in Expt. 4 may have been attributed to low temperatures after treatment applications. Fruit demand for carbohydrate would have been expectedly low during this period, rendering fruit more difficult to thin. Incidentally, 6-BA did not values (i.e., at $500 \mathrm{ppm}) 7 \mathrm{~d}$ after application. These data suggest that poor penetration and/ or activity of metamitron were not responsible for the lack of observed thinning (Fig. 2C). At this particular trial, solar radiation was also high, with the exception of $1 \mathrm{~d}$ (Fig. 1H). On the basis of these data, we would infer that sufficient PN at these light levels could support the reduced fruit demand for carbohydrate from low temperatures. Unfortunately, we did not collect fruit growth rate data to support this contention.

Our results corroborate a previous report that demonstrated the thinning potential of metamitron for 'Conference' pear in two trials at two orchards in The Netherlands (Maas and van der Steeg, 2011). Even though foliar application of metamitron resulted in a significant reduction of fruit set for 'Conference' pear, the relationship was linearly correlated with application rates between 175 to $700 \mathrm{ppm}$ (Maas and van der Steeg, 2011). Under the environmental conditions of our trials, thinning efficacy of metamitron for 'Bartlett' pear typically saturated $\approx 300$ $\mathrm{ppm}$, and higher rates did not produce appreciable, reductions in fruit set. Both climate and cultivar differences may be responsible for the different rate responses observed between their study and ours.

Time of application plays a significant role in the sensitivity of fruit to chemical thinning compounds. We did not adequately test this effect, but the earlier timing (roughly petal fall) of Expt. $1(\approx 7 \mathrm{~mm})$ did not thin, presumably because leaf expansion had only just begun and there was no appreciable leaf surface area for absorbance of the applied chemicals. All other experiments were initiated later in fruit development. Metamitron application to 'Conference' pear also produced more uniform results when applied at 10 - to $12-\mathrm{mm}$ fruit diameter in one trial compared with 6- to $8-\mathrm{mm}$ in a second trial (Maas and van der Steeg, 2011).

The positive effect of metamitron on individual fruit weight appeared to be an indirect consequence of reduced whole tree crop load. Fruit mass in nearly all treatments where thinning was significant was between 200 and $250 \mathrm{~g}$, which is considered optimal for 'Bartlett' pear. For an equivalent crop load, 6-BA did not improve fruit size compared with metamitron despite the previously shown positive effect of 6-BA on cell division activity and subsequent fruit size of apple (Wismer et al., 1995). Metamitron did not markedly alter fruit maturation (evident by similar FF values at harvest) or SSC, the latter is somewhat surprising given reduced crop loads, which would have been expected to increase SSC levels of fruit. Interestingly, TA was higher in fruit of thinned trees in two trials (Tables 1 and 5). Reasons for this are not clear. Fruit ripening was unaffected by thinning agents and, when evaluated, all fruit ripened to acceptable firmness and eating quality.

In conclusion, metamitron thinned 'Bartlett' pear by inducing short-term carbon deficiency. Metamitron induced fruit abscission 
by $\approx 25 \%$ to $40 \%$ compared with controls, and this was associated with a measured decrease in PN. Relatively consistent thinning (four of five trials) was observed, but the dose response was not nearly as pronounced as in other studies. On the basis of these findings, metamitron may have potential as a future thinning compound for 'Bartlett' pear production in the Pacific northwestern United States.

\section{Literature Cited}

Arrington, M., M. Pasa, and T. Einhorn. 2017. Postbloom thinning response of 'Bartlett' pears to abscisic acid. HortScience 52:1765-1771.

Asín, L., P Vilardell, J. Bonany, and S. Alegre. 2009. Effect of 6-BA, NAA and their mixtures on fruit thinning and fruit yield in 'Conference' and 'Blanquilla' pear cultivars. Acta Hort. 8841:379-382.

Basak, A. 2011. Efficiency of fruitlet thinning in apple 'Gala Must' by use of metamitron and artificial shading. J. Fruit Ornamental Res. 19:51-62.

Bates, D., M. Maechler, B. Bolker, and S. Walker. 2015. Fitting linear mixed-effects models using lme4. J. Stat. Softw. 67(1):1-48.

Brunner, P., S. McArtney, and T. Spann. 2014. Impact of metamitron as a thinning compound on apple plants. Acta Hort. 1042:173-181.

Byers, R.E., C.G. Lyons, K.S. Yoder, J.A. Barden, and R.W. Young. 1985. Peach and apple thinning by shading and photosynthetic inhibition. HortScience 60:465-472.

Byers, R.E., C.G. Lyons, J.A. Barden, and R.W. Young. 1986. Desiccating chemicals for bloom thinning of peach and photosynthetic inhibition for post-bloom thinning of apple and peach. Acta Hort. 179:673-680.

Byers, R.E., J.A. Barden, and D.H. Carbaugh. 1990a. Thinning of spur 'Delicious' apples by shade, terbacil, carbaryl and Ethephon. J. Amer. Soc. Hort. Sci. 115:9-13.

Byers, R., J.A. Barden, R.F. Polomski, and D.H. Carbaugh. 1990b. Apple thinning by photosynthetic inhibition. J. Amer. Soc. Hort. Sci. 115: 14-19.
Bubán, T. 2000. The use of benzyladenine in orchard fruit growing: A mini review. Plant Growth Regulat. 32:381-390.

Cline, J.A., K. Carter, A. Gunter, C. Bakker, and A.C. Green. 2018. Response of Bosc and 'Cold Snap' pears to thinning with NAA, 6-BA, ACC, and s-ABA. Can. J. Plant Sci. 98:830-843.

Curetti, M., R. Rodríguez, C. Magdalena, and A. Rodríguez. 2010. Effect of concentration, application volume and addition of a surfactant on response to benzyladenine as thinning agent in 'Williams' pears. Acta Hort. 909:395-401.

Del Valle, T.B., J.A. Barden, and R.E. Byers. 1985. Thinning of peaches by temporary inhibition of photosynthesis by terbacil. J. Amer. Soc. Hort. Sci. 110:804-807.

Dussi, M.C. 2011. Sustainable use of plant bioregulators in pear production. Acta Hort. 909: 353-367.

Einhorn, T., J. Turner, and D. Laraway. 2012. Effect of reflective fabric on yield of mature 'd'Anjou' pear trees. HortScience 47:1580-1585.

Einhorn, T.C. and M. Arrington. 2018. ABA and shade inhibit photosynthesis and increase abscission of 'Bartlett' pears but are not additive. J. Plant Growth Regul. 37:300-308.

Greene, D.W. 2002. Chemicals, timing, and environmental factors involved in thinner efficacy on apple. HortScience 37:477-481.

Greene, D.W. 2012. Influence of abscisic acid and benzyladenine on fruit set and fruit quality of 'Bartlett' pears. HortScience 47:1607-1611.

Greene, D.W., G. Costa, and M. Blanke. 2013. Fruit thinning in pome- and stone-fruit: State of the art. Acta Hort. 998:93-102.

Greene, D.W. and A.N. Lakso. 2013. Prediction of initial set and the thinning response to postbloom chemical thinners on apples. Intl. J. Fruit Sci. 13:430-440.

Greene, D.W., S. McArtney, and T. Spann. 2014. Use of metamitron alone and in combination with 6-benzyladenine for thinning apples. Acta Hort. 1042:167-172.

Lakso, A.N., T.L. Robinson, and M.C. Goffinet. 1996. Influence of fruit competition on size, and the importance of early thinning. New York Fruit Quarterly 4(1):7-9.
Lakso, A.N., T. L. Robinson, and D.W. Greene. 2006. Integration of environment, physiology and fruit abscission via carbon balance modeling-Implications for understanding growth regulator responses. Acta Hort. 727:321-326.

Lakso, A.N. 2011. Early fruit growth and drop-the role of carbon balance in the apple tree. Acta Hort. 903:733-742.

Maas, F. and P. van der Steeg. 2011. Crop load regulation in 'Conference' pears. Acta Hort. 909:369-379.

McArtney, S., J. Obermiller, and C. Arellano. 2012. Comparison of the effects of metamitron on chlorophyll fluorescence and fruit set in apple and peach. HortScience 47:509514.

McArtney, S.J., S.R. Abrams, D.D. Woolard, and P.D. Petracek. 2014. Effects of S-abscisic acid and $(+)-8^{\prime}$-Acetylene abscisic acid on fruit set and stomatal conductance in apple. HortScience 49:763-768.

Musacchi, S. and D.W. Greene. 2017. Innovations in apple tree cultivation to manage crop load and ripening, p. 195-237. In: K. Evans (ed.). Achieving sustainable cultivation of apples. Burleigh Dodds Science Publishing, Cambridge, UK.

Sansavini, S. and S. Musacchi. 1994. Canopy architecture, training and pruning in the modern European pear orchards: An overview. Acta Hort. 367:152-172.

Schröder, M. 2001. Bedeutung und Wirkungsweise chemischer Ausdünnmittel beim Apfel am Beispiel von Ammoniumthiosulfat, Benzyladenin und Harnstoff. Dissertation Universität Hohenheim.

Ward, D. and R.P. Marini. 1999. Growth and development of young apple fruits following applications of ethephon plus carbaryl for thinning. HortScience 34:1057-1059.

Wismer, P.T., J.T.A. Proctor, and D.C. Elfving. 1995. Benzyladenine affects cell division and cell size during apple fruit thinning. J. Amer. Soc. Hort. Sci. 120:802-807.

Zucconi, F. 1981. Regulation of abscission in growing fruit. Acta Hort. 120:89-94. 